\title{
The Importance of Socio-Economic Primary and Secondary Images for Thailand's Tourism: A Case Study of Swedish Tourists
}

\author{
Pattaraphongpan Chaiyamart ${ }^{1}$ \\ ${ }^{1}$ Natural resources science and management, University of Minnesota, St Paul, Minnesota, USA \\ Correspondence: Pattaraphongpan Chaiyamart, Natural resources science and management, University of Minnesota, St \\ Paul, Minnesota, USA.
}

Received: February 20, 2021

Accepted: March 16, 2021

Available online: March 24, 2021

doi:10.11114/ijsss.v9i3.5166

URL: https://doi.org/10.11114/ijsss.v9i3.5166

\begin{abstract}
Swedish tourists constitute one of the most important markets for Thailand's tourism industry. On average, Swedish tourists stay in Thailand 9 days and spend 101 euros per day. Their image of Thailand plays a significant role in deciding to visit or revisit Thailand. The socio-economic primary image consists of five factors: safety and security, feeling at home during their visit to Thailand, money value, the trip exceeding their expectation, and the ease of making trip arrangements. These are crucial factors that determine the level of satisfaction tourists experience during their trip. These factors also help determine whether the tourists visit Thailand again in the future.
\end{abstract}

Keywords: Swedish, tourist, primary image, secondary image, Thailand

\section{Introduction}

Sweden is one of the countries and offers a high standard of living. By law, Sweden guarantees their people a minimum of five weeks of paid vacation every year. Swedish tourists use their free time to travel to many countries around the world, engaging in a wide range of sports and leisure activities. Thailand has become increasingly appealing for Swedish tourists in the last few years; today, Thailand and Spain are their most popular destinations. Indeed, Swedish people have rated Phuket and Bangkok among their most preferred holiday destinations. According to Kotler et al. (2010), there is no doubt that Thailand has successfully created an image that appeals to tourists, leading to a high number of foreign visitors.

Echtner and Ritchie (1991) found that Swedish tourists in Thailand had positive experiences both during and after the visit, making their visit memorable. Their satisfaction level was quite high, being influenced by affective evaluations rather than cognitive evaluations. Milman (1995) found that a number of Swedish tourists who had already visited Thailand wanted to visit Thailand again in the future because of their high level of perceived satisfaction. Echtner and Ritchie (1991) further found that Swedish tourists were willing to recommend Thailand to others as a good destination for a wide variety of visits. This is mainly due to their perceived positive image of Thailand.

The Royal Thai Embassy (2014) found that Sweden had voted for Thailand as one of the safest and most preferred tourist destinations. The same has happened in the past. The main reasons behind this preference are based on three important factors: the sun, the sea, and the beaches that attract tourists, along with the warm tropical climate, which adds positive value to their leisure activities. It is important to understand how these images influence the return of Swedish tourists to Thailand. It is also important to consider the factors that influence the socio-economic primary and secondary images of Thailand held by Swedish tourists. This information would benefit many stakeholders, public and private alike.

\section{Literature Review}

\section{Destination images}

Frias et al. (2008) explain that the destination image is the image that tourists have of a destination. The destination image is associated with the characteristics of a place and affects the travel decisions that tourists make. There are many destinations around the world, and each one has a unique image that plays an important role in attracting visitors. For Gallerza et al. (2002), images are the most powerful sources of motivation for tourists. Images are intangible in nature and can only be felt and experienced, but they are more influential than tangible sources and resources. Additionally, 
images help create perceptions that are more important and decisive than the existing realities themselves. Image formulation depends on the individual's understanding, attitudes, and beliefs. Echtner and Ritchie (1991) explain that researchers have conducted studies in several disciplines-including geography, psychology, and marketing-to understand the impact of destination images in building particular perceptions in the minds of individuals. Fries et al. (2008) added that destination images are associated with the field of psychology, especially imagery research. The image involves a large amount of information associated with the specific place. Earlier research on destination images focused on how the destination image is formed, analyzed, and measured.

However, a number of researchers believe that studying destination images should not be restricted to imagery research, but can be related to a multidisciplinary field involving marketing, sociology, and psychology. An analysis of perception, qualitative benefits, quantitative benefits, and preferences can be used to understand the meaning of destination images in a clear and concise manner. Jenkins (1999) notes that deriving the true meaning of the destination image is quite challenging, as the image varies as according to individual perception. Researchers' definitions and perceptions of an image and its elements also vary, and there is a serious lack of consensus. Furthermore, there is a lack of a conceptual framework, as most of the studies have been conducted from a multi-dimensional point of view rather than by selecting a single approach to describe the image as a notion and concept. This multi-dimensional approach has made research in this field ineffective (Assaker et al., 2011). Crompton (1979) defined the destination image as the ideas, beliefs, and impressions held by different individuals regarding a destination.

\section{Primary and secondary images}

There is a great difference between the primary image and secondary image. The primary image refers to the traveler's own perception. Secondary images are formed through external influences, based on information from other people, the news, and marketing material. The primary image is considered the most important form of the destination image, as it is developed through personal experiences. When tourists visit specific places, their personal experiences help shape how they perceive the destination. In contrast, the secondary image is formed on the basis of preconceived notions, which are shaped by the views and opinions of others, or by personal beliefs and understanding. Secondary images are also formed from the plethora of information available from multiples sources such as family and friends, social media, tv and magazine. Beerli and Martin (2008) state that when individuals visit destinations, they form realistic views and opinions that are more vivid than secondary images.

Thus, it is important to rely on personal experiences to form an opinion about a destination. Molina et al. (2010) also argue that, unless people visit a place for themselves, it is hard for them to form an opinion that is independent of the views of others. Beerli and Martin (2008) further add that people who are thoughtful and careful of their destinations hold more realistic and holistic images than people who are less. However, Reznede et al. (2003) argues that the degree of involvement while staying at a destination and the relationships developed there are more important in forming an image. Therefore, it is crucial to assess the relative importance of primary and secondary images.

\section{Factors affecting destination images}

A number of researchers have emphasized the importance of tourists' image perceptions before and after their visit to the destination (Chen et al., 2007). One of the interesting findings suggests that tourists' perceptions of a destination can change over a period of time (Gallarza et al., 2002). The images of a destination are not permanent or static; rather, they change with shifts in the beliefs, attitudes, and perceptions of the individuals. This also means that images change because people have different kinds of beliefs. Molina et al. (2010) stated that the destination image is based on a number of factors, including accommodations, food, services, and transport facilities. If these factors are successful in creating goodwill and a positive image, then the destination image contributes to building a robust tourist industry (Seongseop et al. 2009). However, these factors have to be experienced by the visitors' first hand.

Images are shaped by the reasoning and emotional interpretations of tourists; this requires understanding the notion of cognitive and affective perception. Cognitive images relate to the individual's knowledge and beliefs about the destination. Affective images relate to the individual's feelings, emotions, and attachments toward the place. Baloglu et al. (1999) state that cognitive and affective perceptions are equally responsible for forming perceptions of a destination.

The research conducted by Seongseop et al. (2009) showed that affective perception plays an important role during and after the visit, whereas cognitive perceptions are important at all times. Cognitive images, on the other hand, depend on knowledge and are thus likely to persist for a long period of time. Cognitive images are also more stable. Despite debates over the importance of cognitive and affective perceptions for the destination image, it is clear that emotional and logical perceptions play a crucial role. The importance of image perception cannot be denied, as it plays a decisive role in the concept of destination images. It also explains how the image changes as the thoughts and perceptions of the tourists change (Josiassen, 2013). 


\section{Dimensions of destination images}

A number of researchers have conducted studies that measure the destination image. Echtner and Ritchie (1991) contributed to the formulation of the destination image framework, stating that the destination image includes functional and psychological characteristics. The former are related to the intangible characteristics of the destination, while the latter are concerned with tangible characteristics. They found that the destination image is based on individual attributes and holistic impressions that need to be understood in a clear manner. They also found that the functional characteristics are directly observable and measurable, whereas the psychological characteristics cannot be measured efficiently. They further found that the destination image includes common features through which different destinations can be compared and evaluated in an effective manner (Beeli \&Martin, 2008).

Destination images are unique to different destinations. (Echtner \& Ritchie, 1991) Thailand is famous for its holistic spas, meditation and health treatments, and sexual services. Different people have different perceptions of different destinations; some people may perceive a destination to be ideal for recreational activities, while others may perceive the same destination as ideal for food and other consumption activities. The dimensions of destination images are not limited, which suggests that a destination image is influenced by a variety of opinions and beliefs.

\section{Destination image formation}

Destination image formation plays an important role in understanding the concept of the destination image. Mackay (1997) stated that the destination image is a mixture of inputs from individuals and from marketers. Destination image formation has a supply and a demand side. The supply side manifests in the form of marketing activities and travel information, while the demand side consists of the demand for information by the tourists. Another interesting point is the difference between the projected image and the received image, which is mainly due to the differences in the information being conveyed either by the communicator or by the receiver. Tasci and Gartner (2007) stated that destination-oriented messages are not guaranteed to reach all people, as personal experiences also play a crucial role. Personal experiences are assumed to influence the image more powerfully than external information.

Images are formed through experiences, media, marketing, and other diverse sources. Many countries enjoy a large amount of goodwill through coverage in international news and media. This has impact on tourists in both negative and positive, which is helping them form an image that is not only appealing but also influential. In the case of Western countries which the majority of tourists do not engage in tourism promotion. This means that high concern of gathering information of their travel destination through different sources is decisive in building a robust image for many countries (Hanlan and Kelly, 2005).

Another interesting dimension of destination image formation is that initial image formation cannot be controlled or managed by the marketers: it is based purely on the beliefs and perceptions of people. Jenkins (1999) points out that the impact of initial memories and initial image formation is quite low, as new experiences and memories tend to replace the older ones. This often helps build a new image, which can either be either strong or weak, based on the perceptions and beliefs of the individuals.

Many researchers believe that, even though destination image formation is a complicated task, it can be understood through the analysis of individuals' beliefs and sentiments. Jenkins (1999) points out that the destination image is never permanent; it is often shaped by political, economic, and social events. Political instability, economic turmoil, social inequality, oppression, and strife can quickly change a positive image of a destination into a negative one. In sum, destination image formation is a robust and systematic process that needs to be understood from the perspective of the individuals in order to improve the destination image of a country (Kotler et al., 2010).

\section{Method}

Data collection

In 2006, I surveyed a total of 128 Swedish tourists, seeking their views and opinions on Thailand as a destination and its related images. The survey was conducted by sending survey link to social media(facebook) who had been to Thailand. The required sample size was calculated from the ratio of estimated parameters and five ratio(Bentler \& Chou, 1987), which is equal to $16 \times 5=80$. Data was collected from a sample of 128 , which is more than sufficient.

This study uses the structural equation model (SEM) because it is a flexible method that can be used for many tasks, such as multiple regression and factor analysis. SEM contains two models: the measurement model and the structural model. Confirmatory factor analysis (CFA) is performed using the measurement model, and multiple regression is performed using the structural model. The CFA is based on theories and previous studies that show how the measurement model deconstructs the overall model to assess the relationship of each factor or indicator to other factors. The factor being assessed, or latent variable, is not measured directly from the survey, but it can be estimated using information from the measured items or indicators that can be fitted into the same latent variable. The high loading of 
indicators within the same factor would be presented, but lower loading indicators would be eliminated. Besides dropping the low loading indicators, the model fit is based on four indices: minimum discrepancy divided by its degree of freedom (CMIN/df) if the value is lower than 5.00 it is considered a good fit(Marsh \& Hocevar, 1985), comparative fit index (CFI) with value of above .90 would be considered a good fit, standardized root mean residual (SRMR) of lower than 0.08 would be considered good fit(Hu\&Bentler, 1999), and root mean square error of approximation (RMSEA) with value of 0.05 would be considered a good fit. Moreover, average variance extracted (AVE) and composite reliability (CR) are needed to confirm that indicators belong within the same factor. AVE above 0.5 and $\mathrm{CR}$ above 0.7 would be considered acceptable values.

After the measurement model is adjusted, the structural model analysis can be performed. This model evaluates the relationship between the independent and the dependent variable, with the model fit based on the four indices mentioned above.

Within the measurement model, there are five indicators of the factors that represent a socio-economic primary image, which relates directly to the experience of a tourist visiting Thailand. These indicators are "feeling at home in Thailand," "personal safety and security," "making travel arrangements for Thailand is easy," "good value for money," and "Thailand exceeded my expectation."

There are multiple regressions within the structural model. The first regression involves two independent variables, the primary image and the secondary image; the dependent variable is the tourist's rating of the destination after the trip. For the second regression, the independent variable is the tourist's rating of the destination after the trip, and the dependent variable is whether the tourist may repeat the trip.

This study was performed this SEM analysis using Amos 22 software.

\section{Results}

Table 1 shows that the model indicates a good fit for all four indices, with a CMIN/df of 1.036, which is below 5.00. CFI is 0.997 , which is above 0.09 . SRMR is 0.045 , which is much lower than 0.08 . Finally, RMSEA is 0.017 , which is below 0.05 .

Table 2 shows how well the indicators fit the factor of the primary image. There are five items with this factor. Using the measurement model, the results of the CFA analysis show that the AVE is 0.398, which is lower than 0.5, but the CR is 0.766, which is higher than 0.7. Although the AVE is insufficient, the CR is good. As shown in Table 1, the model fits for all four indices, indicating a good fit of the model and data.

Table 1. Model Fit

\begin{tabular}{lcc}
\hline Indices & Model fit score & Fit criteria \\
\hline CMIN/df & 1.036 & $<5.00$ is a good fit (Marsh \& Hocevar, \\
CFI & 0.997 & $>0.90$ is a good fit. \\
SRMR & 0.045 & $<0.08$ is a good fit (Hu \& Bentler, \\
RMSEA & 0.017 & $\begin{array}{c}1999) . \\
\text { The smaller, the better; a number }<0.05 \\
\text { is a good fit, } 0.05-0.08 \text { is a reasonable } \\
\text { fit, and }>0.1 \text { is a poor fit. }\end{array}$ \\
\hline
\end{tabular}

Table 2. Average Variance Extracted (AVE) and Composite Reliability (CR)

\begin{tabular}{lcc}
\hline Factor & Average variance extracted (AVE) & Composite reliability (CR) \\
\hline Primary image & 0.398 & 0.766 \\
\hline
\end{tabular}

\section{Description of samples}

Table 3 shows that Swedish tourists' expectations for Thailand are quite positive. Approximately 96.9\% have positive feelings regarding the image of Thailand, which is considered the secondary image because it does not involve their direct experiences in Thailand. Rather, this image is based on their knowledge and information gathered from friends and family. 
Table 3. Expectations before Traveling to Thailand

\begin{tabular}{|c|c|c|}
\hline Expectations before traveling to Thailand & Frequency & Percent \\
\hline Not good & 3 & 2.3 \\
\hline Somewhat good & 4 & 3.1 \\
\hline Good & 39 & 30.5 \\
\hline Very good & 53 & 41.4 \\
\hline Fantastic & 28 & 21.9 \\
\hline No information & 1 & 0.8 \\
\hline Total & 128 & 100.0 \\
\hline
\end{tabular}

Table 4 shows that after the trip, 38.3\% of the Swedish tourists found that their experience was fantastic, and $43.8 \%$ thought that the trip was very good. Only $5.5 \%$ did not have a good experience during their trip to Thailand.

Table 4. Evaluation after Traveling to Thailand

\begin{tabular}{|c|c|c|}
\hline Evaluation after traveling to Thailand & Frequency & Percent \\
\hline Not good & 7 & 5.5 \\
\hline Somewhat good & 2 & 1.6 \\
\hline Good & 13 & 10.2 \\
\hline Very good & 56 & 43.8 \\
\hline Fantastic & 49 & 38.3 \\
\hline No information & 1 & 0.8 \\
\hline Total & 128 & 100.0 \\
\hline
\end{tabular}

Table 5 shows that $60.9 \%$ of the Swedish tourists received information about Thailand from their friends. Approximately $10 \%$ got information about traveling to Thailand from their family. A further $9.4 \%$ got information about Thailand from social media, and $6.3 \%$ got this information from their coworkers and the news.

Table 5. First Hearing about traveling to Thailand

\begin{tabular}{|l|c|c|}
\hline $\begin{array}{l}\text { How did you first hear about the trip to } \\
\text { Thailand }\end{array}$ & Frequency & Percent \\
\hline Friends & 78 & 60.9 \\
\hline Family & 14 & 10.9 \\
\hline Coworker & 8 & 6.3 \\
\hline News & 8 & 6.3 \\
\hline Social media & 12 & 9.4 \\
\hline Other & 4 & 3.1 \\
\hline No information & 4 & 3.1 \\
\hline Total & 128 & 100.0 \\
\hline
\end{tabular}

The results shown in Tables $6,7,8,9$, and 10 reflect the primary image, because Swedish tourists have experienced Thailand directly and expressed their feelings about many aspects of their trip. Table 6 indicates that $64.8 \%$ had the positive experience of feeling at home in Thailand, while $10.9 \%$ of tourists did not feel at home in Thailand.

Table 6. Feeling at Home in Thailand

\begin{tabular}{|l|c|c|}
\hline I feel at home in Thailand. & Frequency & Percent \\
\hline Strongly disagree & 5 & 3.9 \\
\hline Disagree & 9 & 7.0 \\
\hline Neutral & 30 & 23.4 \\
\hline Agree & 42 & 32.8 \\
\hline Strongly agree & 41 & 32.0 \\
\hline No information & 1 & 0.8 \\
\hline Total & 128 & 100.0 \\
\hline
\end{tabular}

Table 7 shows that the tourists' sense of safety and security in Thailand was generally positive, with $8.6 \%$ of respondents strongly agreeing and $34.4 \%$ agreeing with the statement that Thailand is safe. About $20.3 \%$ disagreed with this statement. Only $3.1 \%$ strongly disagreed that Thailand is safe and secure. 
Table 7. Personal Safety and Security in Thailand

\begin{tabular}{|c|c|c|}
\hline $\begin{array}{l}\text { Personal safety and security are high in } \\
\text { Thailand }\end{array}$ & Frequency & Percent \\
\hline Strongly disagree & 4 & 3.1 \\
\hline Disagree & 26 & 20.3 \\
\hline Neutral & 41 & 32.0 \\
\hline Agree & 44 & 34.4 \\
\hline Strongly agree & 11 & 8.6 \\
\hline No information & 2 & 1.6 \\
\hline Total & 128 & 100.0 \\
\hline
\end{tabular}

Table 8 shows that most of the Swedish tourists felt that it is easy to make travel arrangements for Thailand: $22.7 \%$ strongly agreed that it is easy and $50.8 \%$ agreed with this statement. Only $5.5 \%$ disagreed, and only $0.8 \%$ strongly disagreed with the statement.

Table 8. Ease of making travel arrangements for a trip to Thailand

\begin{tabular}{|l|c|c|}
\hline $\begin{array}{l}\text { Making travel arrangements for Thailand is } \\
\text { easy }\end{array}$ & Frequency & Percent \\
\hline Strongly disagree & 1 & 0.8 \\
\hline Disagree & 7 & 5.5 \\
\hline Neutral & 24 & 18.8 \\
\hline Agree & 65 & 50.8 \\
\hline Strongly agree & 29 & 22.7 \\
\hline No information & 2 & 1.6 \\
\hline Total & 128 & 100.0 \\
\hline
\end{tabular}

Table 9 indicates that most Swedish tourists felt that their trip to Thailand had good value for their money: $28.9 \%$ strongly agreed with this statement, and $46.1 \%$ agreed with it. Only a small percentage of the respondents disagreed with this statement: $5.5 \%$ disagreed and $2.3 \%$ strongly disagreed.

Table 9. Good Value for the Money for the Trip to Thailand

\begin{tabular}{|c|c|c|}
\hline $\begin{array}{l}\text { Going to Thailand had good value for the } \\
\text { money }\end{array}$ & Frequency & Percent \\
\hline Strongly disagree & 3 & 2.3 \\
\hline Disagree & 7 & 5.5 \\
\hline Neutral & 20 & 15.6 \\
\hline Agree & 59 & 46.1 \\
\hline Strongly agree & 37 & 28.9 \\
\hline No information & 2 & 1.6 \\
\hline Total & 128 & 100.0 \\
\hline
\end{tabular}

Table 10 shows that after the trip, around $46.1 \%$ of the Swedish tourists agreed that they enjoyed the trip more than they had expected, and $19.5 \%$ strongly agreed with this statement. About $30.5 \%$ felt neutral about how their trip had met their expectations. On the other hand, $2.3 \%$ disagreed with the statement, and only $0.8 \%$ strongly disagreed with it.

Table 10. Overall Evaluation after Traveling to Thailand

\begin{tabular}{|l|c|c|}
\hline $\begin{array}{l}\text { Your visit to Thailand exceeded your } \\
\text { expectations }\end{array}$ & Frequency & Percent \\
\hline Strongly disagree & 1 & 0.8 \\
\hline Disagree & 3 & 2.3 \\
\hline Neutral & 39 & 30.5 \\
\hline Agree & 59 & 46.1 \\
\hline Strongly agree & 25 & 0.8 \\
\hline No information & 1 & 100.0 \\
\hline Total & 128 & \\
\hline
\end{tabular}


Table 11 shows that $89.1 \%$ of the Swedish tourists plan to return to Thailand. Only $0.8 \%$ said that they would not return, and only $8.6 \%$ said that they would maybe return to Thailand for another trip.

Table 11. Possibility of Returning to Thailand

\begin{tabular}{|l|c|c|}
\hline \multicolumn{1}{|c|}{ Will you visit Thailand again? } & Frequency & Percent \\
\hline Definitely yes & 114 & 89.1 \\
\hline Maybe & 11 & 0.6 \\
\hline Probably not & 1 & 0.8 \\
\hline Definitely not & 0 & 1.6 \\
\hline No information & 4 & 100.0 \\
\hline Total & 128 & 0 \\
\hline
\end{tabular}

Table 12 shows that, with the measurement model, five items are statistically significant for $95 \%$ confidence relating to the latent variable of the primary image. The standardized estimate of "feeling at home" is -0.602 . "Personal safety and security" has a standardized estimate of 0.591 , with a P-value of 0.006 . "Making travel arrangements for Thailand is easy" has a standardized estimate of 0.594 , with a P-value of 0.005 . "Good value of money" has a standardized estimate of 0.753 , with a P-value of 0.008 . Finally, the item "Thailand exceeds expectations" has a standardized estimate of 0.599 , with a P-value of 0.004 .

Table 12. Measurement Model: First Order Factors

\begin{tabular}{lccccc}
\hline Parameter & Standardized estimate & S.E. & Lower & Upper & P-value \\
\hline $\begin{array}{l}\text { Primary image } \rightarrow \text { Feeling at home } \\
\text { in Thailand }\end{array}$ & 0.602 & 0.075 & 0.459 & 0.713 & 0.007 \\
$\begin{array}{l}\text { Primary image } \rightarrow \text { Personal safety } \\
\text { and security }\end{array}$ & 0.591 & 0.108 & 0.379 & 0.752 & 0.006 \\
$\begin{array}{l}\text { Primary image } \rightarrow \text { Making travel } \\
\text { arrangements for Thailand is easy }\end{array}$ & 0.594 & 0.069 & 0.461 & 0.686 & 0.005 \\
$\begin{array}{l}\text { Primary image } \rightarrow \text { Good value for } \\
\text { money }\end{array}$ & 0.753 & 0.063 & 0.621 & 0.838 & 0.008 \\
$\begin{array}{l}\text { Primary image } \rightarrow \quad \text { Thailand } \\
\text { exceeded my expectation }\end{array}$ & 0.599 & 0.076 & 0.478 & 0.717 & 0.004 \\
\hline
\end{tabular}

Table 13 shows that the primary image has a positive sign, with a standardized estimate of 0.668 and a P-value of 0.004 , which is statistically significant at $p<0.05$. The secondary image has a standardized estimate of 0.134 , but a P-value of 0.134 , which is not statistically significant at $p>0.05$. This is the first regression with two predictors of the primary image and the secondary image to the dependent variable of the after-trip rating. The other regression path is one predictor of the after-trip rating to the dependent variable of intention to repeat the trip. The results show that the standardized estimate of the after-trip rating to repeating the trip is 0.414 , with a P-value of 0.005 , which is statistically significant at $p<0.05$.

Table 13. The Structural Model Result

\begin{tabular}{|c|c|c|c|c|c|}
\hline Parameter & Standardized estimate & SE & Lower & Upper & P-value \\
\hline $\begin{array}{l}\text { Primary image } \rightarrow \text { After-trip } \\
\text { rating }\end{array}$ & 0.668 & 0.107 & 0.481 & 0.829 & 0.004 \\
\hline $\begin{array}{l}\text { Secondary image } \rightarrow \text { After-trip } \\
\text { rating }\end{array}$ & 0.134 & 0.084 & -0.011 & 0.274 & 0.124 \\
\hline $\begin{array}{l}\text { After-trip rating } \rightarrow \text { Intention } \\
\text { to repeat visit }\end{array}$ & 0.414 & 0.1380 & 0.461 & 0.686 & 0.005 \\
\hline
\end{tabular}

Figure 1 shows the relationship of five items within the primary image and how the primary image and the secondary image impact the level of travel satisfaction. The structural model shows the level of trip satisfaction affects the intention to return for another trip. 


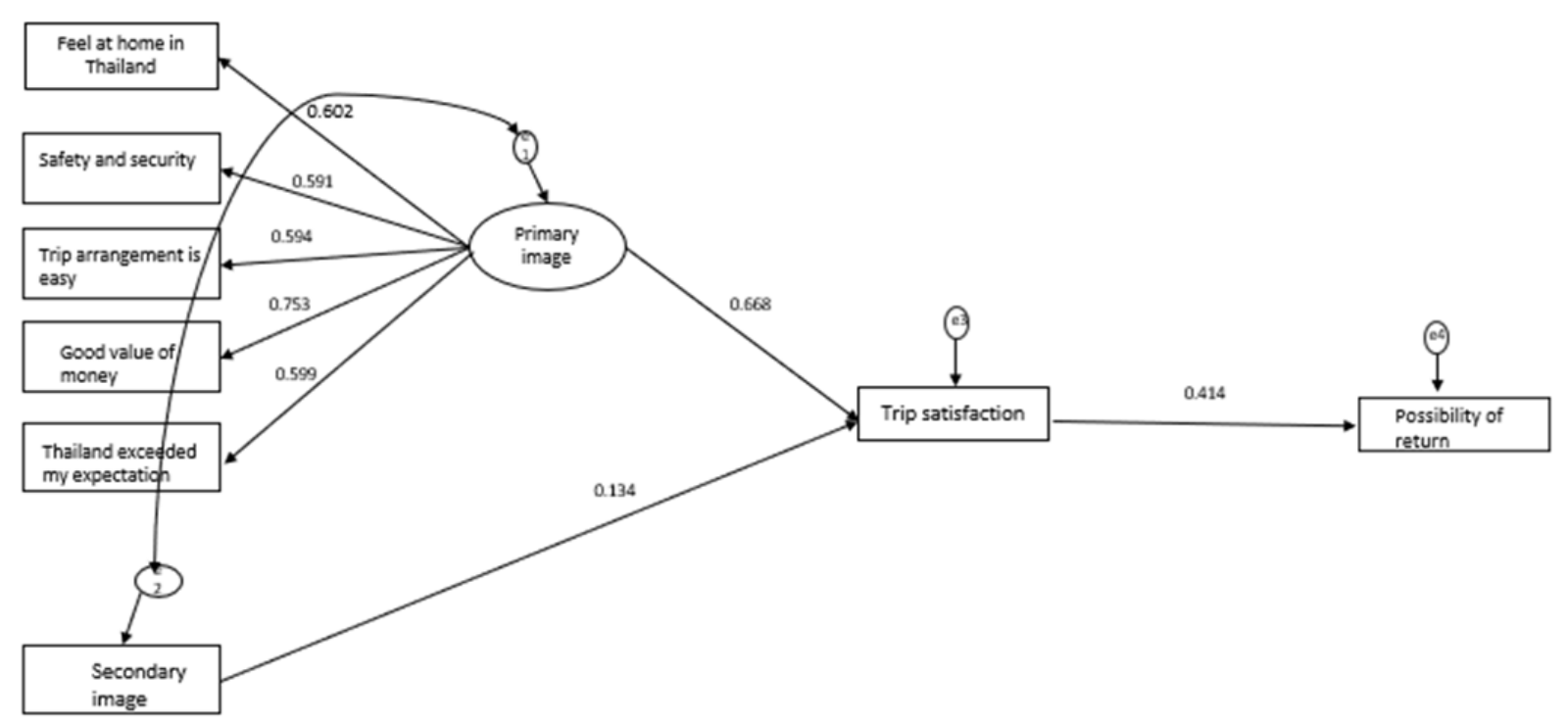

Figure 1. Path diagram of images and its impact to trip satisfaction and possibility of future visit

\section{Discussion}

These results show that the socio-economic primary image is a significant factor to indicate the possible future return of Swedish tourist to Thailand. The tourists' image of the destination is shaped by their experiences from visiting Thailand, including their experiences of local culture, food, sightseeing, and interactions with local people. If the experience has a negative impact, the tourist will remember this and may not return for a second visit. The tourist's feelings toward the destination play an important role in changing the destination's image and the tourists' opinion of it. As shown in the tables representing the primary image factors, once the Swedish tourists directly experienced Thailand, many aspects of the primary image had a positive impact. This is consistent with the study of Beerli and Martin (2008), who show that an individual's visit to a destination forms their realistic view of the destination, which is more vivid than the secondary images. Furthermore, the destination image also positively influences the tourists' perceptions of quality and satisfaction. Many studies have shown that a favorable image increases a tourist's level of satisfaction, and that this positive experience leads to repeating visits (Chi \& $\mathrm{Qu}, 2008)$.

The destination image can last for long time, this would be depending on how strongly tourists believe in the truth of their knowledge that they have regarding the destination. However, the belief can be changed by both primary images and secondary images. My results show that secondary images from the media (9.4\%) or from friends $(60.9 \%)$ and family $(10.9 \%)$ do not have a statistically significant impact on the tourists' image of Thailand. Although news media can, in the later stage of image formation, contribute to changing the image of a country, my results suggest that this does not apply in this particular case.

The destination image plays an important role in the Swedish tourists' decision to visit Thailand and to return to Thailand especially primary image. The socio-economic primary image is key to increasing the tourists' demand, and stakeholders across the public and private sectors can benefit from understanding that experience is crucial to forming the image. Indeed, every time a tourist returns to Thailand, their experiences can affirm the image of the country. The tourists' positive experiences toward socio economic images would have a strong impact on other tourists who have never been to Thailand before, which would consider to return and repeat their visits to Thailand. Moreover, the social and economic primary image for this study is not the same as primary image which is based on Thailand's characteristics such as beautiful nature, food, and weather. Based on the result of this study, it has shown that those five socio economic items of primary image have positive impact to satisfaction level and the future return to Thailand besides those important scenery of Thailand.

Sweden has a high happiness index. Between 2016 and 2020, its happiness index increased from 7.29 to 7.35, while the average happiness index throughout the world was 5.48 points in 2020 (The Global Economy, 2021). The happiness index for Thailand has decreased from 6.47 in 2016 to 6.00 in 2020, due to political issues and economic conditions, but it 
remained above the global average. This shows that the Thai community still has a high level of happiness, even in the face of a difficult time. Thailand has always been known as the land of smiles; this reputation still brings a lot of tourists to the country which is based on the warm hospitality of the local residents whom always welcome tourists to their community.

Sweden is considered one of the safest places in the world, so when Swedish tourists travel aboard, they would like to feel safe. Thailand is considered a safe place to travel to. The robbery rate has decreased from 3 cases per 100,000 people in 2013 to 2 cases per 100,000 people in 2016. The homicide rate has also decreased, from 4.9 cases per 100,000 people in 2013 to 3.2 cases per 100,000 people in 2020 . The robbery rate in Sweden is much higher than in Thailand, with 87 cases per 100,000 people in 2013, though it has since decreased to 86 cases per 100,000 people in 2020 However, Sweden has a very low homicide rate of only 0.9 cases per 100,000 people in 2013 and 1.1 cases per 100,000 people in 2020 (The Global Economy, 2021). Based on this data, Swedish tourists should feel much safer in Thailand than in their home country. Moreover, Thailand is a land of backpackers, and many female tourists can travel to Thailand without any safety problems.

Furthermore, it is easy for Swedish tourists to make travel arrangements for Thailand, since Swedish tourist are exempt from having to get a visa. If length of their visit is within 30 days. The visit can also easily be extended for another 30 days in the case that they would like to extend their visit. The exempt of tourist visa is required for Swedish tourists and it is convenient for them to travel to Thailand anytime they wish for. Furthermore, there are many available tour agencies, and many flights are direct flights, which contributes to the ease of travel.

Considering the currency exchange and the cost of living in Sweden, Swedish tourists become wealthier when traveling in Thailand. The cost of living in Sweden is much higher than that of Thailand, so tourists feel that they gain more value for their money when they travel to Thailand. The consumer price index of Sweden, which represents the price of consumer goods, was 339.34 in December of 2020. Meanwhile, the consumer price index of Thailand was only 99.79. This means that the price of consumer goods in Sweden is almost four times that in Thailand (The Global Economy, 2021). On average, Swedish tourists spent 101 euros per day in Thailand, and stayed around 9.8 days for their trip (Tourism Cambodia, 2015).

A crucial factor in Swedish tourism to Thailand is whether their trip exceeds their expectations. This study shows that the overall feelings from their experiences was positive. This would eventually change any negative beliefs that tourists might have had before they traveled to Thailand. For tourists who already had a positive feeling toward Thailand, a trip that exceeded their expectations would even increase their positive feelings.

\section{Conclusion}

The country's image is an important factor affecting the desire of tourists to visit Thailand. Swedish tourists generally have positive experiences and positive socio-economic primary images of Thailand. Their primary socio-economic primary includes feeling safe and secure while visiting, feeling like they get good value for their money, finding it easy to make the travel arrangements, and feeling at home during their visit to Thailand. When their expectations have been met or exceeded, they form positive socio-economic primary images, which increases their overall satisfaction with their trip and makes them more willing to return to Thailand for another visit. This suggests that the public sector and the private sector would greatly benefit if they consider how to improve Swedish tourists' experiences in Thailand through these five socio economic primary image factors.

\section{References}

Baloglu, S., \& McCleary, K. W. (1999) A Model of Destination Image Formation. Annals of Tourism Research, 26, 868-897. https://doi.org/10.1016/S0160-7383(99)00030-4

Beerli, A., \& Martín, J. D. (2004). A model of destination image formation. Annals of Tourism Research, 31(3), 657-681. https://doi.org/10.1016/j.annals.2004.01.010

Bentler, P. M., \& Chou, C. P. (1987). Practical issues in structural modeling. Sociological Methods \& Research, 16(1), 78-117. https://doi.org/10.1177/0049124187016001004

Chen, C., \& Dung, C. T. (2007). How destination image and evaluative factors affect behavioral intentions. Tourism Management, 28, 1115-1122. https://doi.org/10.1016/j.tourman.2006.07.007

Chi, C. G. Q., \& Qu, H. (2008). Examining the Structural Relationships of Destination Image, Tourist Satisfaction and Destination Loyalty: An Integrated Approach. Tourism Management, 29, 624-636. https://doi.org/10.1016/j.tourman.2007.06.007

Crompton, J. L. (1979). An assessment of the image of Mexico as a vacation destination and the influence of geographical location upon that image. Journal of Travel Research, 17(4), 18-23. https://doi.org/10.1177/004728757901700404 
Echtner, C. M., \& Ritchie, J. R. B. (1991). The Meaning and Measurement of Destination Image. Journal of Travel Studies, 2(2), 2-12.

Frías, D. M., Rodríguez, M. A., \& Castañeda, J. A. (2008). Internet vs. travel agencies on pre-visit Destination image formation: An information processing view. Tourism Management, 29, 163-179. https://doi.org/10.1016/j.tourman.2007.02.020

Gallerza, M. G., Saura, I. G., \& García, H. C. (2002). Destination Image: Towards a Conceptual Framework. Annals of Tourism Research, 29, 56-72. https://doi.org/10.1016/S0160-7383(01)00031-7

Hanlan, J., \& Kelly, S. (2005). Image formation, information sources and an iconic Australian tourist destination. Journal of Vacation Marketing, 11(2), 163-177. https://doi.org/10.1177/1356766705052573

Hu, L. T., \& Bentler, P. M. (1999). Cutoff criteria for fit indexes in covariance structure analysis: Conventional criteria versus new alternatives. Structural Equation Modeling, 6(1), 1-55. https://doi.org/10.1080/10705519909540118

Jenkins O. H. (1999). Understanding and Measuring Tourist Destination Images. International Journal of Tourism Research, 1(1), 1-16. https://doi.org/10.1002/(SICI)1522-1970(199901/02)1:1<1::AID-JTR143>3.0.CO;2-L

Josiassen, A., \& Assaf, G. A. (2013). Look at me-I am flying: The influence of social visibility of Consumption on tourism decisions. Annals of Tourism Research, 40(1), 155-175. https://doi.org/10.1016/j.annals.2012.08.007

Kotler, P., Bowen, J. T., \& Makens, J. C. (2010). Marketing for Hospitality and Tourism (5th ed.). New Jersey: Pearson. Prentice Hall.

MacKay, K. J., \& Fesenmaier, D. R. (1997). Pictorial element of destination in image formation. Annals of Tourism Research, 24(3), 537-565. https://doi.org/10.1016/S0160-7383(97)00011-X

Marsh, H. W., \& Hocevar, D. (1985). Application of confirmatory factor analysis to the study of self-concept: First- and higher order factor models and their invariance across groups. Psychological Bulletin, 97(3), 562-582. https://doi.org/10.1037/0033-2909.97.3.562

Milman, A., \& Pizam, A. (1995). The role of awareness and familiarity with a destination: The central Florida case. Journal of Travel Research, 33(3), 21-27. https://doi.org/10.1177/004728759503300304

Molina, A., Gómez, M., \& Martín-Consuegra, D. (2010). Tourism marketing information and Destination image management. African Journal of Business Management, 4(5), 722-728.

Rezende-Parker, A., Morrison, A. M., \& Ismail. (2003). An exploratory study of the image of Brazil as a travel destination. Journal of Vacation Marketing, 9(3), 243-259. https://doi.org/10.1177/135676670300900304

Seongseop Kim, S., McKercher, B., \& Lee, H. (2009). Tracking tourism destination image Perception. Research Note. Annals of Tourism Research, 36(4), 715-718. https://doi.org/10.1016/j.annals.2009.04.007

Tasci, D. A. A., \& Gartner, W. C. (2007). Destination image and its functional relationship. Journal of Travel Research, 45(4), 413-425. https://doi.org/10.1177/0047287507299569

The global economy. (2021, February 15). Retrieved February 16, 2021, from https://www.theglobaleconomy.com

Tourism of Cambodia. (2021, February 15). Retrieved February 16, 2021, from https://www.tourismcambodia.com/tourist-information/tourist-statistic.htm

\section{Copyrights}

Copyright for this article is retained by the author(s), with first publication rights granted to the journal.

This is an open-access article distributed under the terms and conditions of the Creative Commons Attribution license which permits unrestricted use, distribution, and reproduction in any medium, provided the original work is properly cited. 